\title{
A Literature Review on Population Growth and Economic Development
}

\author{
H.R. Anulawathie Menike* \\ Srilanka \\ *Corresponding Author: H.R. Anulawathie Menike, Srilanka

\begin{abstract}
The connection between population growth and economic development has been a much debated topic ever since the world population passed the two billion mark. A vigorous debate on the relationship between those two factors has been going on in all countries, irrespective of whether they have less developed economies, developed economies or transition economies. Many theories abound, and the first theory states that population growth stimulates economic growth. The second theory views population growth as a phenomenon that adversely affects economic growth. That means the relationship between population growth and economic development can be measured by looking at the impact of population growth on economic development and vice-versa. Hence, the main objective of this paper is to determine the relationship between population growth and economic development by conducting an exhaustive review of the literature. The study reveals that although a steadily growing population might seem to be an obstacle to a country's economic development, most of the countries have accepted the increase in population as a blessing.
\end{abstract}

Keywords: Economic Development, Literature, Population Growth, Relationship

\section{INTRODUCTION}

There exists a close and reciprocal relationship between population growth and economic development in a country. The population in one way constitutes a source of labor that could be utilized to boost the country's production. On the other hand, it could also be seen as a consumer group that uses and exhausts a large quantity of the country's resources. However, certain economists from the earlier times have pointed out that the increase of population and the rapid growth of population in a country is tied to its economy. But the opinion of some other economists is that although the population can grow rapidly in a country, its natural and physical resources are limited, and as a consequence this situation could prove to be an obstacle to the economic development of the country. In the midst of these arguments the demographic transition theory attempts to clarify the relationship between population growth and economic development. It is clear that in the past economists and demographers considered the inter-relationship between population growth and economic development from both an optimistic perspective as well as from a pessimistic perspective. Those who viewed it optimistically adopted a benign attitude towards population increase; that is, they considered it is not necessary to control the population growth of a country. According to them the growth of population does not bring bad results. The pessimists look at it differently and assert that if a country is to attain a higher state of development, the rate of population growth should be reduced. That is, they claim that during the process of economic development population growth should be controlled. All pessimists are of the opinion that a higher fertility rate and the resulting rapid population growth act as a damper on economic development. The main objective of this paper is to examine the literature on the inter-relationship between population growth and economic development from both an optimistic angle as well as from a pessimistic angle.

\section{RELATIONSHIP BETWEEN POPUlation GROWTH AND ECONOMIC DEVELOPMENT}

First, we will examine the effect of population growth on the economic development of a country. On the one hand, through rapid population growth, there will be some economic development. Further, the economy will also be controlled by a large population because a large market has to be supplied. This market will attract the future industrialists who will utilize the most technologically advanced methods to obtain the maximum yield out of the available resources. In this manner the growing population will speed up the economic growth in a country. For example, Japan can be cited as a 
country with a high population but it managed to achieve a high living standard by developing the economy. But when we consider some countries like India, it is clear that the growing population is a big problem that affects the economic development of that country. In this case, the steadily growing population seems to be a hindrance to the country's economic development.

We can also consider the effect of economic development on population growth. In a country that has not yet attained satisfactory economic development, the birth and death rates will be rather high. The birth rates will be steep due to a number of factors such as the early marriage of women, more home centered role with fewer working women due to social beliefs and customs, and the expectation that the children will generate an income for their families someday. At the same time the death rate will also be high due to the consumption of less nutritious food, poor sanitary conditions and nonavailability of advanced medical facilities. But when a country enters an era of sound economic development, more nutritious food will be consumed by the people and advanced medical care will also improve the life expectancy of the people. Due to the medical advances, ample supply of food items, and better sanitation brought forth by economic development there will be a sharp drop in the death rate. But as a result of all the comforts made accessible by the economy, the birth rate will continue to remain at a high level. The combined effect of all this will be that the growth of population will speed up and there will be a less manageable situation caused by the sharp rise in the number of people.

However, when a country builds up a more robust economy, the birth rate usually begins to decline. That happens because economic progress makes people realize the appropriateness of having smaller families and also drives them to take an interest in planning their families. The reason for this is economic growth is always accompanied by a rise in prices and increase in the cost of living. Then children are considered not as a treasure by parents but as a burden for them. The prevalence of small families and low death rates are special characteristics of this period.

\section{LITERATURE REVIEW}

According to optimists like Keynes, development in a country without population growth will cause problems. When the population increases, they expect the savings and investments also to increase. When the population decreases, the production, capital accumulation, employment, incomes and savings will also decrease and may negatively affect the development. According to Keynes, the growth of population will cause a strong demand for goods that will make it possible to establish a good market as well as increase the demand for capital. Optimists like Arthur Lewis (1954) and Jorgenson (1961) have declared that population growth will speed up economic development.

Boserup (1981) says that using improved technology can have a positive impact on production. Some demographers have concluded that slower population growth would be beneficial for development in most developing countries and that the relationship between population and development is contextual (The National Research Council, 1986). The study by Kelly and Schmidt (1995) has also concluded that population size and density have a transitional impact on economic growth. Other studies have reported that the shift in age distribution pattern has had a significant impact on economic growth through savings and investments (Mason, 1988; Bloom and Williamson, 1997).

According to Bloom and Canning, "There is strong evidence that demographic change has a major impact on the course of economic growth. For example, they say rising life expectancy tends to increase savings and education level, increasing the investment in physical and human capital"(Bloom and Canning, 1999). Coale and Hoover have expressed their views about the relationship between population growth and economic growth. According to them, an economy based on agriculture shows high mortality and fertility rates (Coaleand Hoover, 1958). Generally, due to disasters and floods, the rate of mortality is high in this field. On account of poor nutrition, bad health habits, limited public health programs and inadequate sanitary facilities, the mortality rate will be at a high level. However, countries that change over from agricultural products to industrial and technological products will increase their production capacity and thus improve their economy (Coaleand Hoover, 1958).

Livingston (2002)mentions that Malthus and neo-Malthusians believe that population growth is negatively correlated with economic growth. But Julian Simon argues that the correlation is positive. According to Simon (1977), the newer generation of job-seekers who enter the workforce will have better education than the previous generation of workers, and so the former will be more productive than the latter, leading to greater economic development. 
Mason (1988) has investigated the correlation between savings, economic growth and demographic change. He has studied the economic consequences of the developing countries' growing populations. According to him, a rapidly growing population requires increasing investment to maintain the labor to capital ratio. Therefore, the labor productivity increases. Besides this simple relationship between population growth, savings and economic growth, the increase of human capital, institutional and restructuring problems also play an important role. Mason also investigates the importance of the role played by a high rate of savings in ensuring rapid economic growth and whether rapid population growth impedes efforts to raise the rate of savings. According to him there is empirical evidence that domestic savings are the major source of investment. A cross-country comparison reveals a correlation between the gross domestic savings ratio and the gross domestic investment ratio of 0.74 and the slope of the corresponding regression line is 0.63 , which indicates that a one percent increase in savings results in an increase of investment by 0.63 percentage points.

An empirical study was done by Bloom and Williamson in 1998 on population growth and economic growth (Bloom and Williamson, 1998). The aim of this study was to show the role of demographic factors in explaining the boom in economic growth rates in East Asia during the period 1965-90. As the authors stress, the realization of the demographic dividend in East Asia was made possible due to effective social, economic and political institutions and policies. In that study they have estimated growth using an econometric model. The World Bank database used for this econometric analysis contains statistics of 78 (Asian and non-Asian) countries, covering the time period from1965 to 1990. The dependent variable is the growth rate of real GDP per capita in 1965-90 in purchasing power parity. Bloom and Williamson found that the economically active population (aged 15-64) exerted a strong positive impact on GDP per capita growth rates. They announced "An increase of 1 percent in the growth rate of the working-age population is associated with an increase of 1.46 per cent in the growth rate of GDP per capita. In the case of an increase of 1 percent in the growth rate of the overall population, that is associated with a decrease of 1.03 per cent in the growth rate of GDP per capita.

Bloom, Canning and Malaney (1999) have examined the links between demographic change and economic growth in Asia during the period 1965-90. The main objective of that study was to examine the linkages between population change and economic growth. For that purpose they collected the data for 70 countries from all regions of the world, and covering the period 1965-90. The results indicated that both East Asia's economic success and South Asia's economic failure are primarily attributable to the influence of demographics, specifically, differences in health status, dependency burdens and the spatial distribution and concentration of people. Further, Bloom and others showed that the overall rate of population growth had little effect on economic growth, but changes in life expectancy, age structure and population density had a significant impact on economic growth.

Deaton and Paxson (1999) have been studying the relationship between demographic structure, economic growth and savings. Their study focused on Taiwan. They examined this topic within the framework of the life cycle hypothesis. They also used a time-series of cross sectional household surveys in Taiwan to estimate the age profiles for consumption, income, and savings. They have used these results to investigate the extent to which demographic change and economic growth can account for the increase in Taiwan's savings rate.

Kothare (1999) pointed out that India has become one of the world's fastest growing economies, primarily due to the rise in population growth exercising a positive effect on its long term economic growth. India is now ranked as one of the top producers of agricultural products and is a leading nation in terms of GDP among developing countries. He says that a variety of factors have contributed to the growth of India's economy. These can be described briefly. Due to the rising population a large labor force was created. In keeping with its fiscal policies, India spent money on education to instruct youth and adults, which helped them to play a productive role in India's economy. Due to the better education provided to the job-seekers, India was able to generate and harnessa better trained employment force. The resulting high rates of fruitful employment meant that India's economic sectors, mainly agriculture and industry, began increasing their productivity.

Graham and Beeler (2000) have tested the effect of population growth on economic development, as well as the effect of economic development on population growth. They wanted to determine how these effects change over time. Their study was based on the works of Simon (1989), Graham (1993) and Barlow (1994). Graham and Beeler presented their arguments and provided a model for testing 
their ideas. They pointed out that while rapid population growth is not harmful for long term economic growth, it can have disturbing effects in the short term. Also, they found that efforts at speeding up economic development in nations experiencing rapid population growth could actually turn out to be counterproductive. Furthermore, their study showed that development actually has a positive effect on population growth and this effect will continue over at least a thirty year period.

Bloom, Canning and Sevilla (2001) have examined the relationship between demographic change and economic growth in some specific regions of the world. In the case of East Asia, a demographic transition occurred there with relative rapidity, spanning a 50 to 75 year period and this has proved to be the fastest demographic transition witnessed to date. Modern transitions occur faster because less developed countries gain the benefit of knowledge, experience and technology developed by the more advanced countries. According to Bloom, Canning and Sevilla (2001), the East Asian demographic transition was one of the critical factors that was behind the region's fantastic economic growth. Between 1965 and 1990, per capita income rose annually by over 6 percent. With the benefits of a good education and a liberalized trade environment, the younger generation was absorbed into the job market and into gainful employment, thereby raising the region's capacity for economic production. The region's working age population grew nearly four times faster than its dependent population between 1965 and 1990. Therefore, this favorable demographic change increased income growth, and the income growth had the effect of pushing down the population growth. In addition, East Asia's high savings rates were also affected by the demographic transition, as the baby boom generation began to enter the workforce.

Bloom, Canning and Sevilla (2001) also examined the situation regarding South and South-east Asia's demographic transition and its impact on the economy. They found that South and South-east Asia have lagged behind East Asia in the demographic transition, but lately Southeast Asia has begun to benefit from the demographic dividend. In fact, Southeast Asia has already gained considerable economic benefit from its demographic change (which accounts for about $1 \%$ of per capita annual income growth) but is likely to see this benefit reduced over the next 25 years as the population ages.

A study was done by Mason (2001) to examine the relationship between demographic change and economic development in East Asia. The study concentrated on the experiences of six East Asian economies: Japan, South Korea, Taiwan, Singapore, Thailand and Indonesia over the period 19601990. Mason says that in 1960 the countries of East Asia faced many difficult problems. In the view of many experts of that period, rapid population growth was one of the most intractable of those problems.

Bloom and Canning (2001) have discussed three different mechanisms by which demography can influence economic growth: (a) labor market effect, (b) an effect on savings and capital accumulation, and (c) an effect on educational enrolment and human capital. Labor market effects can be determined by looking at dependency ratios, which reveal significant age structure effects. Effects on savings and capital accumulation are based on the assumption of imperfect international capital markets, thus implying that national savings roughly equal national investment. When concern effects on educational enrolment and human capital, due to increased rates of return for education, high youth dependency ratios may impede high school enrolment rates.

As the authors argue, reduction in the death rate can increase the labor force percentage, generate higher savings, and increase returns on education. Later on, a higher proportion of old age dependents may increase productivity through higher capital intensity. Further, they say that besides age structure, population density may affect economic growth.

KannanNavaneetham (2002) studied the age based structural transition and its linkages with the economic growth of countries in South Asia (Bangladesh, India and Sri Lanka) and South-east Asia (Indonesia, Malaysia, Philippines, Singapore and Thailand).This study found that the age based structural transition was not uniform among the countries of South and South-east Asia. The differences in age based structural transition are due to differences in the fertility and mortality rates among these countries. The window of opportunity or demographic bonus had a positive impact on the economic growth of all South-east Asian countries except the Philippines. The per capita GDP growth rate increased sharply at the beginning of the shift in the age distribution of the population in the South-east Asian countries of Singapore, Thailand and Malaysia. However, the per capita GDP growth rate has not continued at the same level in later years even though the decline in the dependent population and increase in the working age population continued. 
Further, he found that the South Asian countries benefited little from the age related structural transition. The South Asian countries did not perform as well in terms of economic growth compared to the South-east Asian countries at the onset of their age structural transition. The reason could be that at the onset of the age structural transition all of the South-east Asian countries, excluding the Philippines were open to trade.

Further, the study found that the age group of 25-49 years had a significant negative impact on economic growth. Because this age group of the population consumes most of its earningson consumption it is able to save little. This was true in Indonesia, Philippines and Thailand. But the age group 50-64 had a positive effect on economic growth due to its higher rate of savings and lower consumption. This was true in Singapore and Malaysia. However, the 65+age group will have a negative impact on economic growth. As expected, the effect was negative in Singapore. Surprisingly, the age group $65+$ positively influenced economic growth in the Philippines. On the whole, this study declares that the demographic transition had an encouraging effect on the economic growth of countries in South and South-east Asia.

Mason and Westley (2002) pointed out that six Asian countries, viz. Japan, South Korea, Taiwan, Singapore, Thailand and Indonesia achieved unparalleled economic development during the period from 1960 to 1990. Between 1960 and 1990, childbearing and population growth rates dropped steeply in those countries. Beginning in the 1960s, these six countries adopted and vigorously pursued policies that successfully slowed population growth and accelerated economic development. This has demonstrated that changes in the population age structure, childbearing rate, and life expectancy of these countries created a very favorable environment for rapid economic growth.

Beaudry and Collard (2003) investigated the impact that growth in the working age population had on economic performance across the richest industrialized countries. They applied cross-country regressions covering the periods from 1960 to 1974 and from 1975 to 1997, respectively. In those countries, income per adult in 1985 had exceeded US \$ 10,000. The countries surveyed were Australia, Austria, Belgium, Canada, Denmark, Finland, France, Germany, Iceland, Italy, Japan, The Netherlands, New Zealand, Norway, Sweden, Switzerland, the United Kingdom and the USA.

The results obtained for the 1960 to 1974 period differ significantly from those obtained for the 1975 to 1997 period. The coefficients capturing the influence of the working age population were small and insignificant in the first period. But they observed a significant correlation for the second period. Between 1975 and 1997, countries with higher growth of the adult population exhibited lower growth in output per worker but higher growth in employment. Their estimates suggest that, "A country with a yearly adult population growth rate $1 \%$ higher than average experienced poorer growth in output per worker of approximately $1 \%$ per year" (Beaudry and Collard, 2003).

A study was done by Wong and de Carvalho in 2004on the age structure transition and its emerging challenges in Brazil. According to their study, some improvements related to health, nutrition and education among children and adolescents were achieved, in part due to the age structure transition. Among the working age population, the mature population (aged 25 to 64) that usually has high activity rates and is represented by important taxpayers will increase in relative and absolute terms at least until 2045. In contrast, the junior segment (aged 15 to 24) consisting of those entering the labor force for the first time, will probably have negative growth rates. Thus, the ratio of the junior labor force to the mature labor force, which is an indicator of the demand for generation of new employment, showed a downward trend in Brazil.

Prskawetz, Kogel, Sanderson and Seherbov (2004) have done a study about the effects of age structure on economic growth. They have devised a new model to predict the effects of age structure change on economic growth. But the authors of this study have followed Bloom and Williamson's (1998) view. Bloom and Williamson made use of the estimated coefficients on population growth rates and growth rates of the economically active population (15-64 age group). They estimated by using a cross country regression of economic growth applied to 78 developing and developed countries. They focused on the past (1965-1990) to forecast the future (1990-2025) influence of demographic change on economic growth. However, Prskawetz, Kogel, Sanderson and Seherbov (2004) looked to India as a case study for their approach. From the findings of this study they pointed out that change in the age structure has a significant negative effect on the youth dependency ratio and the output per working age person, as well as a significant positive effect on social infrastructure. 
They also found that there is a 95 percent chance that the predicted growth rate in the output per working age person in 2035 will be between 3.8 and 4.6 percent compared to the value of 4.1 percent in 1995-2000.Changing India's social infrastructure variable from its value in 1995-2000 to the level currently observed in Singapore will increase the average rate of growth of output per working age person by about 1 percentage point. However, according to them, the probability of improving India's social infrastructure and future economic growth might be higher than their predictions that consider only the change in the age structure.

Wang and Mason (2005) studied about the demographic dividend and prospects for economic development in China. They have pointed out that during the last 25 years the People's Republic of China has experienced demographic as well as economic changes of significant proportions. China has become in the last two decades, one of the most active and fastest growing economies in the world. Especially, the "first demographic dividend" has been responsible for this rapid development (mainly due to an increase in the number of working age population). The first dividend refers to the steady increase in the growth rate of per capita income. That occurs when the productive population grows at a faster rate than the total population. However, this period with its growth trend must ultimately come to an end. As the demographic transition proceeds, growth of the working age population will gradually become slower than that of the total population, as the proportion of the ageing population rises. This will have the effect of reducing the growth of per capita output and per capita consumption. On the whole, they note that the demographic factor proved very favorable to China's economic growth over the last quarter century.

Cai Fang and Wang Dewen (2006) have investigated the impact of demographic transition on China's economic growth. Then they have divided the contribution of demographic factors into two categories as demographic dividends and demographic debts. During the current stage of development in China, the higher ratio of working-age population can be utilized as a favorable factor to promote fast economic growth. Also, they have pointed out that the Chinese demographic transition has contributed 15-25 percent to economic growth and 5-21 percent to the savings rate in the reform era. With the acceleration in the ageing of the population, the demographic dividend will be reduced by the end of 2013. This reduction of the working age population will cause a rise in wages. In addition to this, the study reveals that the total dependency ratio in China will further decline from 42.6 percent in 2000 to 38.8 percent in 2013, a 2.6 percentage point drop. Therefore, the demographic dividend will continue to make a contribution to China's economic growth before the turning point is reached in 2013, when the demographic dividend will transform into a demographic debt. Further, they suggest that the ageing population will continue to increase in the coming decades. Therefore, China will need to establish a sustainable pension system to safeguard society in the era of an ageing population and create some critical policy adjustments.

Batini, Callen and McKibbin (2006)devised and presented an econometric model that can be used to examine the economic implications of demographic transition over the next 80 years for Japan, the United States, other industrial countries and certain developing regions of the world. This model suggests that in the advanced countries population ageing will likely reduce per capita growth rates in the future, while in developing countries increases in the relative size of the working age population could lead to stronger per capita growth, provided the additional labor resources are effectively utilized. They also pointed out that large changes could occur in savings, investment and current account balances over the next 80 years as a result of demographic change.

A study was done by Croix, Lindh and Malmberg (2007)on the demographic changes and economic growth history of Sweden during the long period from 1750 to 2050. They found that demographic change is a key determinant of the long-term growth in per capita income. Their analysis used the case of Sweden as a kind of laboratory since very reliable demographic and economic data are available for that country, dating from 1750 onwards. Their study has pointed out that the same shift in mortality and age structure that account for the growth in per capita income across 111 countries over the last 40 years, also accounts for the long-term increase in Swedish per capita income from the early $19^{\text {th }}$ century onwards.

\section{CONCLUSION}

It is clear that in the past, economists and demographers considered the inter-relationship between population growth and economic development in an optimistic manner as well as in a pessimistic 
way. When considering those with an optimistic outlook, they adopted a welcome attitude towards population increase -that is, they considered it was not necessary to limit the population of a country. But the pessimists express the view that if a country is to reach a proper state of development, the speed of population growth should be reduced. According to the foregoing discussion, it is clear that although a steadily growing population might appear to be a hindrance to a country's economic development, most of the countries have in practice accepted their population as a blessing.

\section{REFERENCES}

[1] BatiniNicoletta, Callen Tim and McKibbin W (2006), "The Global Impact of Demographic Change", IMF Working Paper, WP/06/9, International Monetary Fund.

[2] Beaudry P and Collard F (2003), "Recent Technological and Economic Change among Industrialized Countries: Insights from Population Growth", Scandinavian Journal of Economics, 105(3), pp. 441-463.

[3] Bloom D.E \& Williamson J.G (1997), "Demographic Transition and Economic Miracles in Emerging Asia", Working Paper 6268, Cambridge, NBER.

[4] Bloom D.E \& Williamson J.G (1998), "Demographic Transition and Economic Miracles in Emerging Asia", The World Bank Economic Review, Vol. 12, No. 3, pp. 419-455.

[5] Bloom D.E and Canning D (1999), "Economic Development and the Demographic Transition: The Role of Cumulative Causality", Harvard University, Cambridge, pp.1-32.

[6] Bloom D.E and Canning D (2001), "Cumulative Causality, Economic Growth and the Demographic Transition", In: N Birdsall A, Kelly and S. Sinding (eds.), Population Matters: Demographic Change, Economic Growth and Poverty in the Developing World, Oxford: Oxford University Press, pp. 165-197.

[7] Bloom D.E, Canning D and Malaney P.N (1999), "Demographic Change and Economic Growth in Asia", CID Working Paper No. 15, Centre for International Development at Harvard University, pp. 1-62.

[8] Bloom D.E, Canning D and Sevilla J (2001), "Economic Growth and the Demographic Transition", NBER Working Paper, No. 8685, pp. 2-48

[9] Boserup E (1981), Population and Technological Change: A Study of Long-Term Trends, The University of Chicago Press, Chicago

[10] Chi Fang and Wang Deven (2006), "Demographic Transition and Economic Growth in China", Paper Presentation at the International Conference on the Dragon and the Elephant: China and India's Economic Reform, Shanghai, China.

[11] Coale A.C and Hoover, E.M (1958), Population Growth and Economic Development in Low Income Countries: A Case Study of India, Princeton University Press, Princeton, Chapter. 2.

[12] Croix D De La, Lindh T \&Malmberg Bo (2007), "Demographic Change and Economic Growth in Sweden: 1750-2050", Department of Economics, University of Louvain, Belgium.

[13] Deaton A and Christina H Paxson (1995), "The Effects of Economic and Population Growth on National Saving and Inequality", Demography, 34(1), pp. 97-114.

[14] Echrlich, P.R (1968), "The Population Bomb", Bulletin, New York.

[15] Graham R.J and Beeler D (2000), "Population Growth and Economic Development", Southern Sociological Society Annual Meeting, New Orleans, Lee University, pp. 2-15.

[16] Kelly A and Schmidt R (1995), "Aggregate Population and Economic Growth Correlation: The Role of the Components of Demographic Change", Demography, 32, pp. 543-555.

[17] Lewis, Arthur W (1954), "Economic Development with Unlimited Supply of Labour", The Manchester School, Reprinted in Agrawal, A.N. and S.P.Singh (1958), "The Economics of Under-development", pp. 400-449.

[18] Livingston B (2002), "The One-child Policy: An Economic Analysis", http//www.lclark.edu/econ/China. htm.

[19] Mason A (1988), "Savings, Economic Growth and Demographic Change", Population and Development Review, Vol.14, No.1, pp. 113-144.

[20] Mason A (2001), "Population Change and Economic Development: What We Learned from the East Asia Experience?'Working Paper No. 01-3, Paper Presented at the Meetings of the Western Economic Association International, San Francisco.

[21] Mason A and Westley S.B (2002), "Population Change and Economic Development: Success Stories from Asia", The Future of Population Asia, Honolulu: East-West Centre, pp. 97-110.

[22] National Research Council (1986), Population Growth and Economic Development: Policy Questions, National Academy Press, Washington DC.

[23] Navaneetham, K (2002), "Age Structure Transition and Economic Growth: Evidence from South and Southeast Asia”, Asian Meta Centre Research Paper Series, No.7, Asian Meta Centre for Population and Sustainable Development Analysis, Asia Research Institute, National University of Singapore, pp.1-27. 
[24] Prskawetz A, Kogal T, Sanderson W.C and Scherbov, S (2004), "The Effects of Age Structure on Economic Growth: An Application of Probabilistic Forcasting in India", Working Papers, Vienna Institute of Demography, Austrian Academy of Science.

[25] Simon J (1977), The Economics of Population Growth, Princeton, N.J, Princeton University Press.

[26] Wang F and Mason A (2005), "Demographic Dividend and Prospects for Economic Development in China", Paper Prepared for UN Expert Group Meeting on Social and Economic Implications of Changing Population Age Structures, Maxico City, August 31 - Sep. 2, pp. 141-153.

[27] Wong L.R and De Carvalho, J.A.M (2004), “Age Structural Transition in Brazil-Demographic Bonuses and emerging Challenges", Paper presented to the seminar on Age Structural Transition: Demographic Bonuses, but Emerging Challenges for Population and Sustainable Development, Sponsored by the Committee for International Cooperation in National Research in Demography (CICRED), Paris

\section{AUTHOR'S BIOGRAPHY}

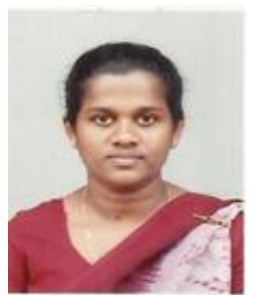

H.R. Anulawathie Menike was born in SriLanka and She received her BA and MA degrees in Economics from the University of Kelaniya and University of Sri Jayewardenepura respectively. She earned her Doctor of Philosophy (Ph.D.) degree in Economics from the University of Pune, India, in 2011. Currently, Dr. Anulawathie Menike is involved in research on population issues in Sri Lanka and other developed and developing countries.

Citation: H.R. Anulawathie Menike. "A Literature Review on Population Growth and Economic Development". International Journal of Humanities Social Sciences and Education (IJHSSE), vol 5, no. 5, 2018, pp. 67-74. doi: http://dx.doi.org/10.20431/2349-0381.0505009.

Copyright: (C) 2018 Authors. This is an open-access article distributed under the terms of the Creative Commons Attribution License, which permits unrestricted use, distribution, and reproduction in any medium, provided the original author and source are credited. 